\title{
Some Fundamental Aspects of Highly Reactive Iron Coke Production
}

\author{
Seiji NOMURA, ${ }^{1)}$ Hidetoshi TERASHIMA, ${ }^{2)}$ Eiji SATO $^{3)}$ and Masaaki NAITO ${ }^{1)}$ \\ 1) Environment \& Process Technology Center, Nippon Steel Corporation, 20-1, Shintomi, Futtsu, Chiba $293-8511$ Japan. \\ E-mail: nomura.seiji@nsc.co.jp $\quad$ 2) Nagoya Works, Nippon Steel Corporation, 5-3, Tokaimachi, Tokai, Aichi $476-8686$ \\ Japan. $\quad 3)$ Hokkai Iron \& Coke Corp., 12 Nakamachi, Muroran, Hokkaido 050-0087 Japan.
}

(Received on February 5, 2007; accepted on March 30, 2007; originally published in Tetsu-to-Hagané, Vol. 92, 2006, No. 12, pp. 849-856)

\begin{abstract}
It is important to develop the production and utilization technology of highly reactive coke in order to improve the efficiency of blast furnace reactions. In this study, some fundamental aspects of highly reactive iron coke produced in a coke oven chamber were investigated. First, the effects of catalytic Fe powder addition to coal before carbonization on coke strength were investigated. The addition of Fe powder decreased the coal caking property and hence the resultant coke drum index $\left(\mathrm{DI}^{150}{ }_{15}\right)$. On the other hand it increased coke reactivity (JIS coke reactivity index and CRI) to a great extent. This means that the caking property of blended coals needs to be adjusted higher to produce iron coke with proper strength and high reactivity. Secondly, it was shown that the iron ore reacts with silica brick at $1200^{\circ} \mathrm{C}$ in a condition similar to that in a coke oven chamber. The iron ore and silica reacted to produce fayalite $\left(2 \mathrm{FeO} \cdot \mathrm{SiO}_{2}\right)$ and the brick was damaged. On the other hand, it was proven that the iron ore does not react with silica brick at $1100^{\circ} \mathrm{C}$ in the above condition. Based on this fundamental study, iron coke with proper strength and high reactivity was successfully produced in a coke oven chamber on a commercial scale by adjusting the coal blend composition and the coke oven temperature. Furthermore it was revealed that about $70 \%$ of iron in iron ore powder added to coal was reduced to metallic iron during carbonization.
\end{abstract}

KEY WORDS: iron coke; coke reactivity; catalyst; ironmaking; cokemaking; drum index; fayalite; reaction efficiency; blast furnace; thermal reserve zone.

\section{Introduction}

Improvement in the efficiency of blast furnace reactions during the blast furnace ironmaking process is important since it has the potential to allow a decrease in the reducing agent rate (the amount (in $\mathrm{kg}$ ) of reducing agents such as coke and coal required to produce $1000 \mathrm{~kg}$ of pig iron) as well as $\mathrm{CO}_{2}$ emissions. Naito et al. ${ }^{1)}$ proposed a technology that dramatically improves the reaction efficiency in blast furnaces by decreasing the temperature of the thermal reserve zone through the use of highly reactive coke. Here the reactivity of coke refers to the reaction rate of coke with $\mathrm{CO}_{2}$ (solution loss reaction $\mathrm{C}+\mathrm{CO}_{2}=2 \mathrm{CO}$ ). We investigated methods to produce highly reactive coke with high strength that can be used in an actual blast furnace, by utilizing the catalytic effect, and reported that $\mathrm{Fe}$ and $\mathrm{Ca}$ are promising as catalysts to improve the coke reactivity in the condition of the thermal reserve zone in a blast furnace, i.e. relatively low temperature (approximately $1000^{\circ} \mathrm{C}$ ), $\mathrm{CO}_{2} / \mathrm{CO}$ mixture, low weight loss (at most $20 \%$ ). ${ }^{2,3}$ )

There are two basic methods of adding the catalyst to the coke ${ }^{2,3)}$ : (1) the 'post-addition of catalyst to coke' method, where the catalyst and/or catalyst solution is coated onto the coke after the coke is pushed out of the coke oven chamber, and (2) the 'pre-addition of catalyst to coke' method, where the catalyst is mixed with coal before the mixture is carbonized in the coke oven chamber. Regarding the former method (1), we reported ${ }^{2)}$ that the reaction rate of $\mathrm{Fe}$ or $\mathrm{Ca}$ catalyst-coated highly reactive coke produced by the 'post-addition of catalyst to coke' method is kept high until the weight loss reaches $10 \%$ and that $70 \%$ of the catalyst coated on the coke surface still remains after the brittle coke surface is separated to generate coke breeze by drop impacts, since the catalyst penetrates into the open pores on the coke surface. Regarding the latter method (2), we investigated the 'pre-addition of Ca to coke' method and reported $^{3)}$ that the use of the strong, highly reactive 'lump' Ca-rich coke produced by blending a Ca-rich coal in Muroran No. 2 Blast Furnace for a long period caused a decrease in the reducing agent rate.

On the other hand, for the 'pre-addition of Fe to coke' method, 'iron-coke' produced by carbonizing the mixture of coal and Fe powder in a coke oven chamber is known ${ }^{4}$; however, the production method of iron coke to satisfy the coke quality such as the strength and reactivity required for an actual blast furnace operation is unclear. Furthermore, it has been suggested ${ }^{4,5)}$ that there is a concern in the iron coke production that $\mathrm{FeO}$ may react with $\mathrm{SiO}_{2}$, namely the 
main component of the coke oven wall brick, during carbonization, producing a low melting compound, fayalite $\left(2 \mathrm{FeO} \cdot \mathrm{SiO}_{2}\right)$ and damaging the wall brick. It is not clear under what condition and to what extent the coke oven wall silica brick is damaged during the iron coke production in an actual coke oven chamber.

Therefore in this report, in order to clarify the production method of iron coke to satisfy the coke quality such as strength and reactivity required for an actual blast furnace operation, we investigated the effect of catalytic Fe powder (fine iron ore powder, iron agent) added to coal before carbonization on coke strength and the effect of Fe powder on the silica brick in actual coke oven chamber conditions. Then, based on the fundamental study, iron coke was produced in a commercial scale coke oven chamber.

\section{Effect of Catalytic Fe Powder Addition on Coke Quality}

\subsection{Experimental}

2.1.1. Evaluation of the Effect of Catalytic Fe Powder Addition on Coal Caking Properties

Five types of coals (Table 1) were used in the test. Coal $\mathrm{A}$ is a single coal and coals B1-B4 are blended coals. Here the total dilatation and the maximum fluidity of coals B1-B4 are measured values. Iron ore powder (Table 2) and iron compound $\left(\mathrm{Fe}_{2} \mathrm{O}_{3}, \mathrm{Fe}_{3} \mathrm{O}_{4}\right)$ powders were used as the iron catalyst since it is easy to mix powder catalysts with coal and powder catalysts have a large surface area. Coke breeze was also used as a reference standard sample to evaluate the effect of catalytic Fe powder addition on coal caking properties. The catalytic Fe powder and coke breeze were added to the coal at an addition rate of 1 to 10 mass $\%$ and the dilatation and the fluidity ${ }^{6}$ were measured. The catalytic Fe powder and coke breeze were sieved with 1.18, $0.60,0.25,0.15 \mathrm{~mm}$ sieves and the particle size distribution on a weight basis $\left(f_{\mathrm{w}}(\%)\right)$ was obtained (Table 3). Next the

Table 1. Characterization data for the coals used.

\begin{tabular}{|c|c|c|c|c|}
\hline \multirow[t]{2}{*}{ Coal } & \multicolumn{2}{|c|}{$\begin{array}{l}\text { Proximate analysis } \\
\text { (mass \% db) }\end{array}$} & \multirow{2}{*}{\begin{tabular}{|c|} 
Total \\
dilatation \\
$(\%)$
\end{tabular}} & \multirow{2}{*}{$\begin{array}{c}\text { Maximum } \\
\text { fluidity } \\
(\log \text { MF/ddpm) }\end{array}$} \\
\hline & VM & Ash & & \\
\hline $\bar{A}$ & 23.6 & 9.0 & 103 & 2.98 \\
\hline B1 & 28.8 & 8.8 & 25 & 1.93 \\
\hline B2 & 26.2 & 8.9 & 39 & 2.56 \\
\hline B3 & 26.5 & 9.2 & 74 & 2.70 \\
\hline B4 & 26.8 & 9.0 & 80 & n.a. \\
\hline
\end{tabular}

Table 2. Chemical compositions of the iron ore.

\begin{tabular}{|r|c|c|c|c|c|c|c|c|}
\hline \multicolumn{7}{|c|}{ Chemical composition (mass \%) } \\
\hline T.Fe & $\mathrm{FeO}$ & $\mathrm{Fe}_{2} \mathrm{O}_{3}$ & $\mathrm{SiO}_{2}$ & $\mathrm{Al}_{2} \mathrm{O}_{3}$ & $\mathrm{CaO}$ & $\mathrm{MgO}$ & $\mathrm{Mn}$ & $\mathrm{TiO}_{2}$ \\
\hline 66.76 & 17.35 & 76.16 & 4.52 & 0.37 & 0.18 & 0.07 & 0.06 & 0.06 \\
\hline
\end{tabular}

particle size distribution on a number basis $\left(f_{\mathrm{n}}(\%)\right)$ was obtained by assuming that the mean size of each increment $\left(D_{\mathrm{p}}\right)$ is $1.500,0.890,0.425,0.200$ and $0.075 \mathrm{~mm}$. Then assuming that the particle is completely spherical, the specific surface average size $D_{\mathrm{s}}(\mathrm{cm})=\left[\sum f_{\mathrm{n}}\left(D_{\mathrm{p}} / 10\right)^{3}\right] /\left[\sum f_{\mathrm{n}}\left(D_{\mathrm{p}} / 10\right)^{2}\right]$ and the specific surface area, $s_{0}\left(\mathrm{~cm}^{-1}\right)=6 / D_{\mathrm{s}}$ were obtained.

\subsubsection{Carbonization Test}

The iron coke was produced by carbonizing the mixtures of the coal and the iron ore powder in an electrically heated test coke oven. ${ }^{7}$ The mixtures of coals A, B1 and B2 $(85 \%<3 \mathrm{~mm}$, the moisture content $6 \%)$ and the iron ore powder were prepared according to the addition ratio in Table 4. The bulk density of the mixtures of the coal and the iron ore powder was measured by dropping $34 \mathrm{~kg}$ of the Test 3, 4 and 5 samples from a height of $2 \mathrm{~m}$ into a cubic container $(305 \times 305 \times 305){ }^{8}{ }^{8}$ Then the sample was charged in a galvanized steel box ( $420 \mathrm{~mm}$ wide, $600 \mathrm{~mm}$ long and $400 \mathrm{~mm}$ high) at the measured bulk density depending on the iron ore powder addition ratio (Table 4). The box was then placed in an electrically heated test oven and carbonized for $18.5 \mathrm{~h}$ by controlling the temperature of the electric heating elements so that the temperature rise curve in the coal is equivalent to that in an actual coke oven with the flue temperature of $1250^{\circ} \mathrm{C}$. Furthermore, iron ore, $\mathrm{Fe}_{2} \mathrm{O}_{3}$ and $\mathrm{Fe}_{3} \mathrm{O}_{4}$ powder were added to coal $\mathrm{B} 4(80 \%$ $<3 \mathrm{~mm}$, the moisture content $4 \%$ ) at an addition ratio of 2.5 to 7.5 mass $\%$ and the sample was charged at a bulk density of $830 \mathrm{dry}-\mathrm{kg} / \mathrm{m}^{3}$ and carbonized in the test coke oven.

\subsubsection{Coke Quality Measurement}

After the coke was quenched with nitrogen, the coke sample was stabilized by the drop shatter test apparatus, $\left.{ }^{9}\right)$ where the sample was dropped from a position of $2 \mathrm{~m}$ high, three times. The JIS drum index of coke (DI ${ }_{15}^{150}$, a percentage of coke mass retained on sieves with $15 \mathrm{~mm}$ apertures to the original mass of the coke sample after 150 revolutions in the JIS drum tester $)^{9)}$ was measured. Moreover, the JIS coke reactivity index (JIS R $\mathrm{e})$, ${ }^{9)}$ the CRI (Coke Reactivity Index: the percentage of weight loss to the original

Table 4. Blending ratio of iron ore powder and bulk density in the carbonization test.

\begin{tabular}{|c|c|c|c|c|}
\hline \multirow{2}{*}{ Test } & \multirow{2}{*}{ Coal } & \multirow{2}{*}{$\begin{array}{c}\text { Iron ore } \\
\text { powder }\end{array}$} & \multicolumn{2}{|c|}{ Bulk density (dry,kg/m ${ }^{3}$ ) } \\
\cline { 4 - 5 } & & (mass\%) & coal + iron ore & coal \\
\hline 1 & A & 0 & 724 & 724 \\
\hline 2 & A & 10 & 777 & 719 \\
\hline 3 & B1 & 0 & 724 & 724 \\
\hline 4 & B1 & 10 & 777 & 719 \\
\hline 5 & B1 & 20 & 845 & 728 \\
\hline 6 & B2 & 0 & 724 & 724 \\
\hline 7 & B2 & 10 & 777 & 719 \\
\hline
\end{tabular}

Table 3. Size distribution and specific surface area of iron ore powders and coke breeze.

\begin{tabular}{|c|c|c|c|c|c|c|c|c|c|c|c|c|c|c|}
\hline & \multicolumn{5}{|c|}{$f_{w}$ (mass \%) (measured) } & \multicolumn{5}{|c|}{$f_{n}(\%)$ (calculated) } & \multirow{3}{*}{$\begin{array}{c}D_{s} \\
(\mathrm{~cm})\end{array}$} & \multirow{3}{*}{$\begin{array}{c}\mathrm{s}_{0} \\
\left(\mathrm{~cm}^{-1}\right)\end{array}$} & \multirow{3}{*}{$\begin{array}{c}\rho \\
\left(\mathrm{g} / \mathrm{cm}^{3}\right)\end{array}$} & \multirow{3}{*}{$\begin{array}{c}\mathrm{s}_{0} / \rho \\
\left(\mathrm{cm}^{2} / \mathrm{g}\right)\end{array}$} \\
\hline Sieve size $(\mathrm{mm})$ & $>1.18$ & $>0.60$ & $>0.25$ & $>0.15$ & -0.15 & $>1.18$ & $>0.60$ & $>0.25$ & $>0.15$ & -0.15 & & & & \\
\hline$D_{p}(m m)$ & 1.500 & 0.890 & 0.425 & 0.200 & 0.075 & 1.500 & 0.890 & 0.425 & 0.200 & 0.075 & & & & \\
\hline Iron ore powder & 0.0 & 0.0 & 0.0 & 1.1 & 98.9 & 0.0 & 0.0 & 0.0 & 0.1 & 99.9 & 0.0076 & 795 & 5.0 & 159 \\
\hline $\mathrm{Fe}_{2} \mathrm{O}_{3}$ & 0.0 & 7.6 & 16.9 & 16.6 & 58.8 & 0.0 & 0.0 & 0.2 & 1.5 & 98.4 & 0.0109 & 550 & 5.3 & 104 \\
\hline $\mathrm{Fe}_{3} \mathrm{O}_{4}$ & 0.0 & 1.3 & 61.7 & 22.9 & 14.1 & 0.0 & 0.0 & 2.2 & 7.7 & 90.1 & 0.0222 & 270 & 5.1 & 53 \\
\hline Coke breeze & 0.1 & 1.3 & 8.3 & 8.9 & 81.5 & 0.0 & 0.0 & 0.1 & 0.6 & 99.4 & 0.0087 & 691 & 1.0 & 691 \\
\hline
\end{tabular}




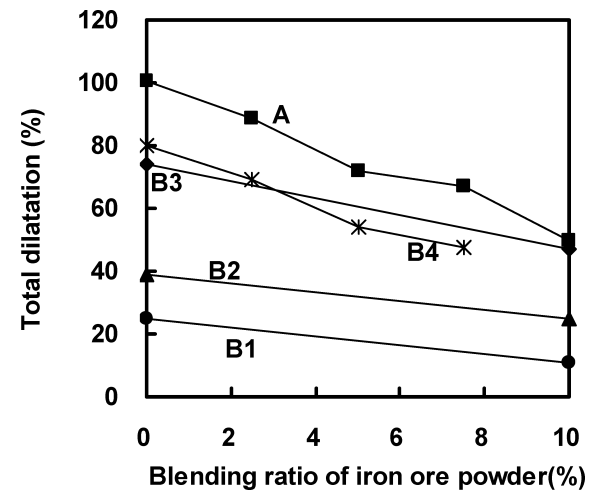

Fig. 1. Effect of iron ore powder addition to coal on total dilatation.

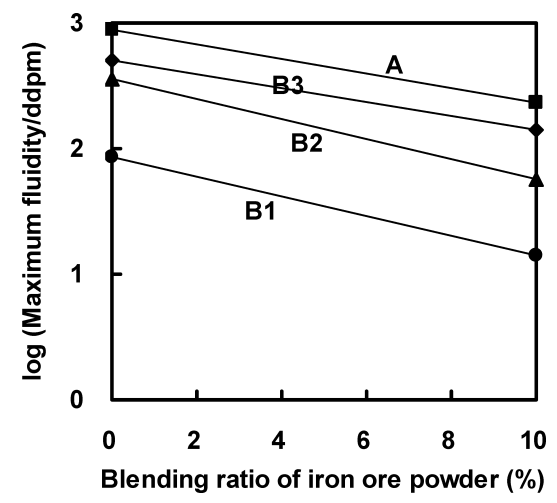

Fig. 2. Effect of iron ore powder addition to coal on maximum fluidity.

coke mass after reaction under $\mathrm{CO}_{2}$ at $1100^{\circ} \mathrm{C}$ for $2 \mathrm{~h}$ ) and CSR (Coke Strength after Reaction: percentage of coke mass retained on a sieve with $9.5 \mathrm{~mm}$ apertures to the mass of reacted coke sample after 600 revolutions in the I-type drum tester ${ }^{10)}$ were measured. Furthermore, a long coke lump with a length of about $200 \mathrm{~mm}$ was collected and a cross-section of the coke parallel to the test oven wall at $100 \mathrm{~mm}$ from the oven wall (the so-called "body" part) was observed by a microscope.

\subsection{Results and Discussion}

2.2.1. The Effect of Catalytic Fe Powder Addition on Coal Caking Properties

Figures 1 and $\mathbf{2}$ show that the addition of iron ore powder decreases the total dilatation and maximum fluidity of coal and that $10 \%$ blending of the iron ore powder to coal reduces the total dilatation by $50 \%$ and maximum fluidity by $20-40 \%$. Figure 3 shows that the addition of iron compound $\left(\mathrm{Fe}_{2} \mathrm{O}_{3}, \mathrm{Fe}_{3} \mathrm{O}_{4}\right)$ powders also decreases the total dilatation. As shown in Fig. 3, under the same mass blending ratio, the addition of iron ore powder decreases the total dilatation to the same extent as the addition of coke breeze but to a smaller degree than the addition of $\mathrm{Fe}_{2} \mathrm{O}_{3}$ and $\mathrm{Fe}_{3} \mathrm{O}_{4}$. The reasons for the decrease in the total dilatation might be explained by a 'physical' and 'chemical' effect of additives. A 'physical' effect is one where a non-fusible 'inert' substance like coke breeze promotes gas leakage from the molten coal and hence inhibits dilatation. A 'chemical' effect is one where some chemical interaction between additives and coal inhibits dilatation. Assuming

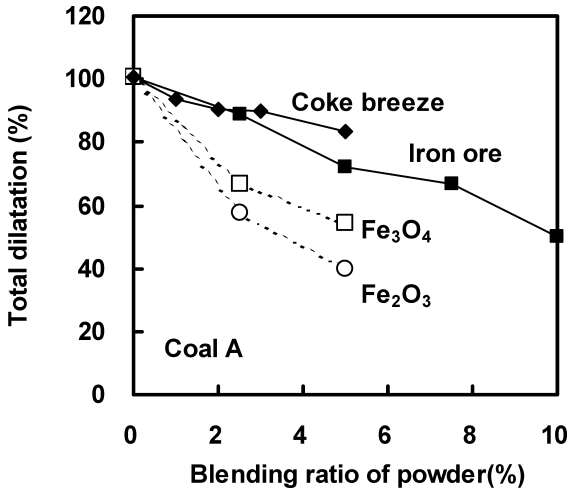

Fig. 3. Effect of iron ore powder and iron reagent addition to coal on total dilatation.

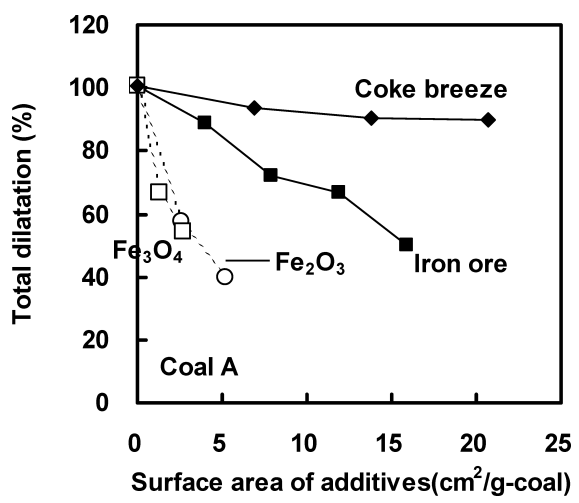

Fig. 4. The relationship between surface area of additives and total dilatation.

that the gas leakage from the molten coal strongly depends on the surface area of inert additives, the 'physical' effect of additives on the coal caking property can be considered the same under the same surface area of additives. In order to separate these effects, the relationship between the surface area of additives per unit mass of coal and the total dilatation is plotted in Fig. 4. It is clear that under the same surface area of additives, the dilatation inhibition by additives is in the order of $\mathrm{Fe}_{2} \mathrm{O}_{3} \sim \mathrm{Fe}_{3} \mathrm{O}_{4}>$ iron ore powder $>$ coke breeze. This suggests that the dilatation inhibition is somewhat caused by chemical interactions between iron oxide powder and coal. Barking et al. ${ }^{5)}$ reported that hematite $\left(\mathrm{Fe}_{2} \mathrm{O}_{3}\right)$ decreases the coal caking property more than magnetite $\left(\mathrm{Fe}_{3} \mathrm{O}_{4}\right)$ because the atomic ratio $\mathrm{O} / \mathrm{Fe}$ of the former is larger than that of the latter and suggested the inhibition of the caking property by the chemical interaction. However, in our study, the order of the dilatation inhibition does not correspond with the order of atomic ratio $\mathrm{O} / \mathrm{Fe}\left(\mathrm{Fe}_{2} \mathrm{O}_{3}>\right.$ iron ore powder $\left.>\mathrm{Fe}_{3} \mathrm{O}_{4}\right)$. Further study on this matter is required.

\subsubsection{The Effect of Catalytic Fe Powder Addition on} Coke Quality

(1) Coke Strength $\left(\mathrm{DI}^{150}{ }_{15}\right)$

As shown in Fig. 5, the addition of iron catalyst powder greatly decreases $\mathrm{DI}^{150}{ }_{15}$. Twenty percent addition of iron ore powder to B1 coal decreased $\mathrm{DI}^{150}{ }_{15}$ to as low as 41.7. As shown in Fig. 6, the bulk density of coal/iron ore mixture increases by increasing the blending ratio of iron ore powder; however, the bulk density of coal itself does not 


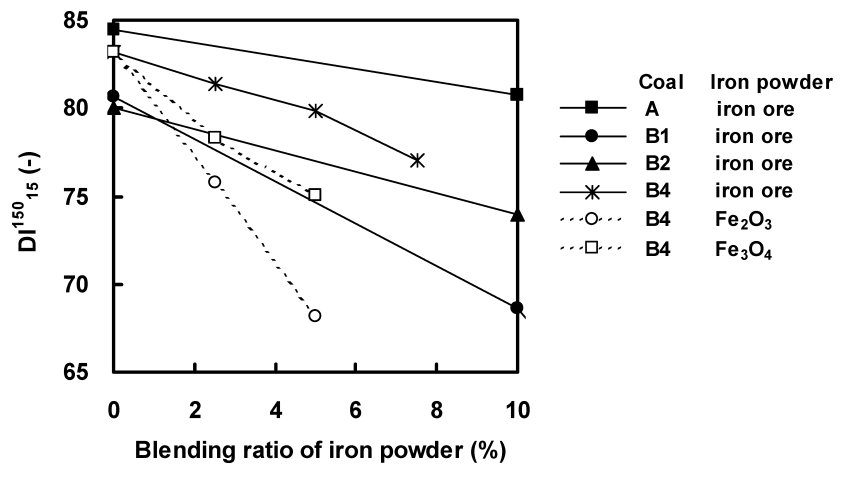

Fig. 5. Effect of iron catalyst powder addition to coal on $\mathrm{DI}^{150}{ }_{15}$.

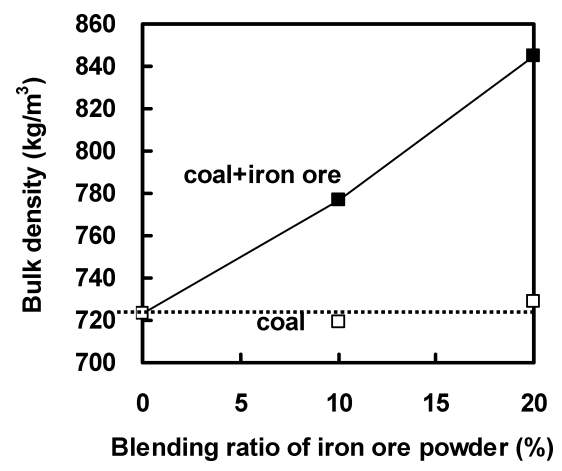

Fig. 6. The bulk density of coal/iron ore mixture.

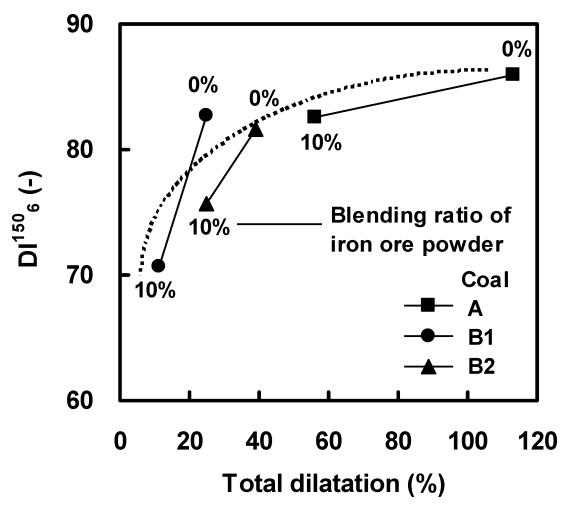

Fig. 7. Effect of total dilatation on $\mathrm{DI}^{150}{ }_{6}$.

change (here the bulk density of coal itself was calculated by assuming the density of iron ore powder is 5000 $\left.\left[\mathrm{kg} / \mathrm{m}^{3}\right]\right)$. On one hand, the addition of iron ore powder to coal increases coal bulk density by an increase in the fall energy due to the increase in the mass of mixture. On the other hand, this inhibits the packing of coal particles. It is considered that these opposite effects canceled each other out and that the coal bulk density itself changed little by the addition of iron ore powder. A great decrease in $\mathrm{DI}^{150}{ }_{15}$ with little change in the coal bulk density itself suggests that the dilatation inhibition by iron ore powder addition caused insufficient adhesion of coal particles. A decrease in the total dilatation of coal reduces the surface breakage strength of coke $\left(\mathrm{DI}^{150}{ }_{6}\right) \cdot{ }^{7,11)} \mathrm{In}$ this study, as shown in Fig. 7 , the addition of iron ore powder decreases the total dilatation of coal, which results in a decrease in $\mathrm{DI}^{150}{ }_{6}$. Therefore, the caking property of blended coals needs to be adjusted higher to produce iron coke with proper coke

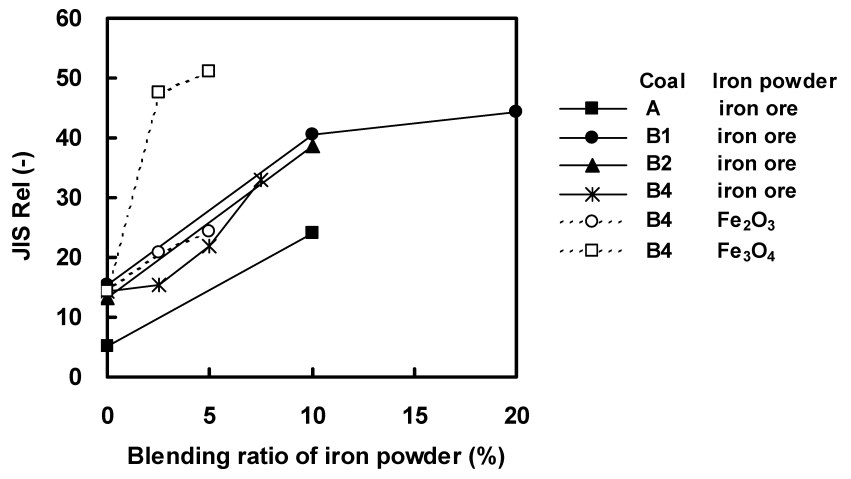

Fig. 8. Effect of iron catalyst powder addition to coal on JIS coke reactivity index.

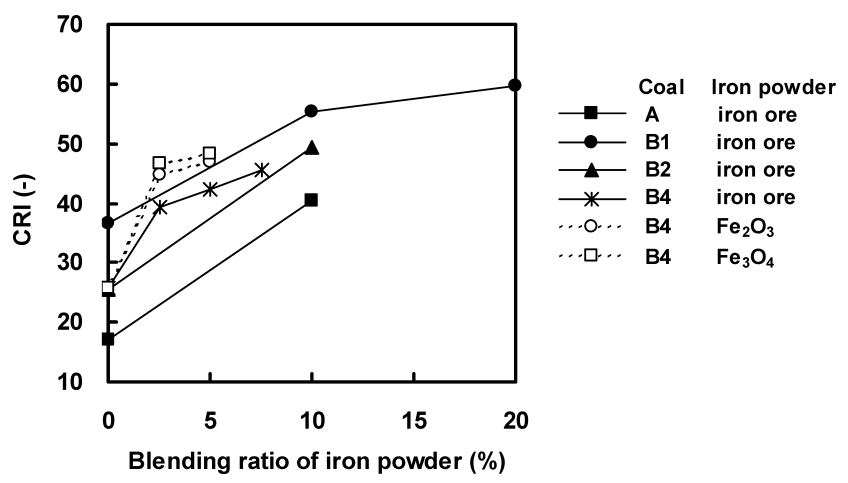

Fig. 9. Effect of iron catalyst powder addition to coal on CRI.

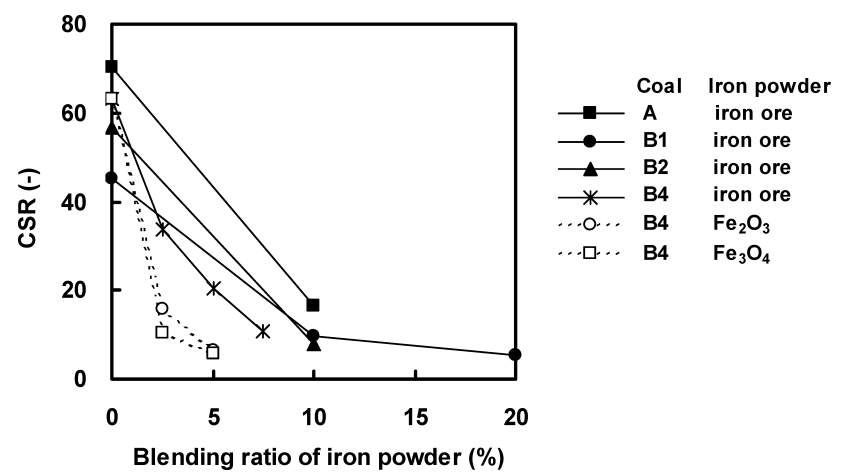

Fig. 10. Effect of iron catalyst powder addition to coal on CSR.

strength $\left(\mathrm{DI}^{150}{ }_{15}\right)$.

\section{(2) Coke Reactivity}

As shown in Figs. 8 and 9, the addition of iron catalyst powder increases the JIS coke reactivity index and CRI to a great extent. This is due to the catalytic effect of iron ${ }^{12-14)}$ on the reaction between $\mathrm{C}$ and $\mathrm{CO}_{2}$. CSR, which stands for a strength index after reaction, decreases by increasing the addition ratio of the iron catalyst powder as shown in Fig. 10. Since CSR is a strength index after a constant period of reaction, a highly reactive coke with higher CRI inevitably shows lower CSR as shown in Fig. 11. On the other hand, it is suggested ${ }^{15-17)}$ that since the amount of $\mathrm{C}$ consumed by solution loss reaction in a blast furnace is nearly constant, the strength of coke after the reaction should be evaluated after a constant weight loss. Further study is necessary on the evaluation of post-reaction strength of highly reactive coke. 


\subsubsection{Optical Microscopic Analysis of Fe Powder Added Coke}

Figure 12 shows the optical microscopic images of coke in the case of no iron ore powder addition and $10 \%$ addition. Iron ore powder (identified as the bright and white parts in the images) exists in the coke structure (coke wall); however, there are some spaces around the iron ore powder
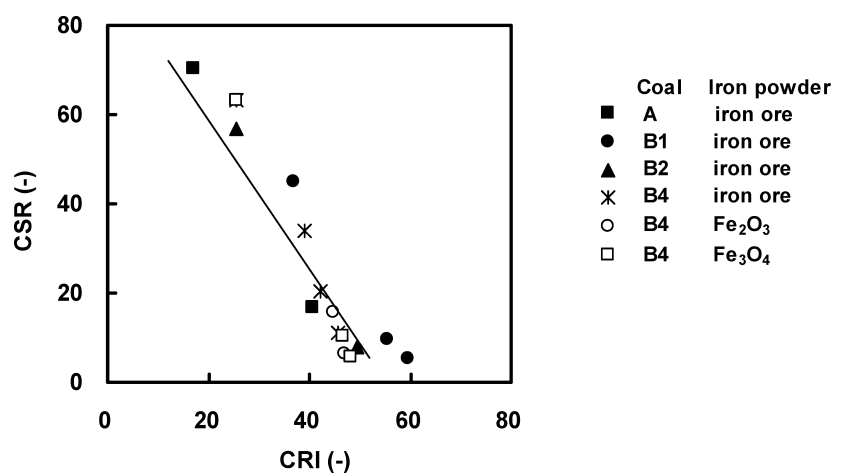

Fig. 11. The relationship between CRI and CSR.
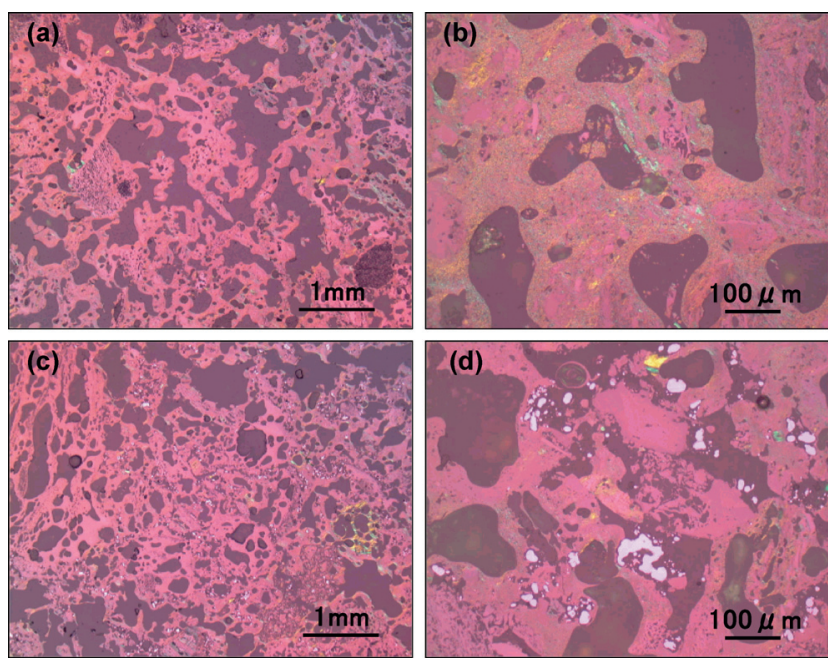

Fig. 12. The optical microscopic images of coke (a) no addition ( $\times 25)$, (b) no addition $(\times 200)$, (c) $10 \%$ iron ore powder addition $(\times 25)$, (d) $10 \%$ iron ore powder addition (×200).

(b)

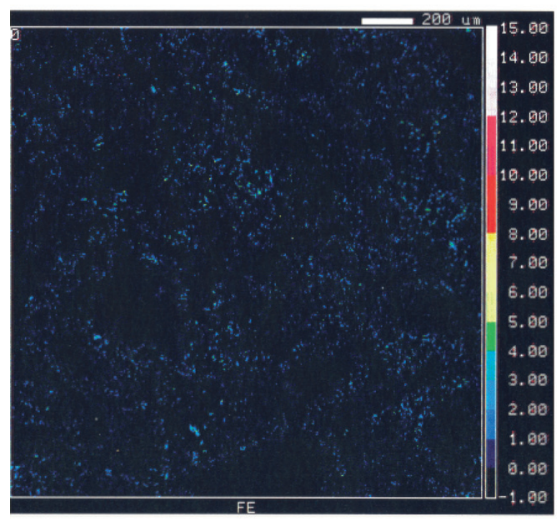

particles and they do not adhere to coke. The addition of iron ore powder decreases the total dilatation of coal, which suggests that the expansion of coal particles is inhibited and the bonding between coal particles becomes weak. Moreover, it is observed that iron ore powders exist around original coal particles and the distribution of iron ore powder particles in coke reflects the original shape of coal particles. From a macro point of view, iron ore particles are uniformly dispersed in coke; however, from a micro point of view, they are condensed surrounding the original coal particles with a size of $1-2 \mathrm{~mm}$.

\subsubsection{Reduction of Iron Ore Powder during the Co-car- bonization of Coal/Iron Ore Powder Mixture}

The yield of iron ore powder after co-carbonization of coal/iron ore powder mixture was calculated by the following equation: [(measured mass of coke derived from coal/iron ore powder mixture)-(calculated mass of the coke derived from coal)]/[mass of iron ore powder]. The yields of iron ore powder in Tests 2, 4, 5 and 7 are 58, 65, 64 and $64 \%$, respectively, which shows a great weight loss of the iron ore powder during co-carbonization of the
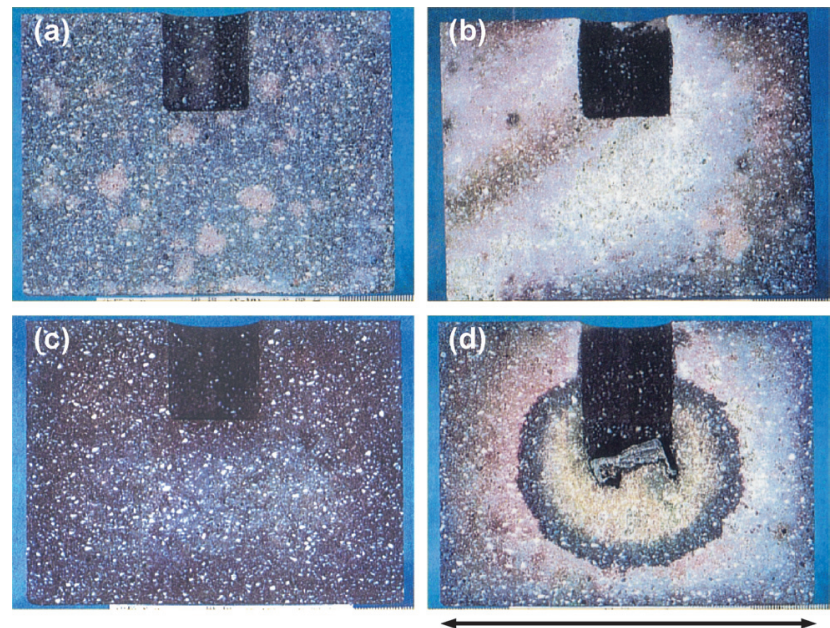

$130 \mathrm{~mm}$

Fig. 14. The cross-sectional view of the heat-treated silica brick retort (a) no addition, $1100^{\circ} \mathrm{C}$; (b) iron ore powder, $1100^{\circ} \mathrm{C}$; (c) no addition, $1200^{\circ} \mathrm{C}$; (d) iron ore powder, $1200^{\circ} \mathrm{C}$.

(d)

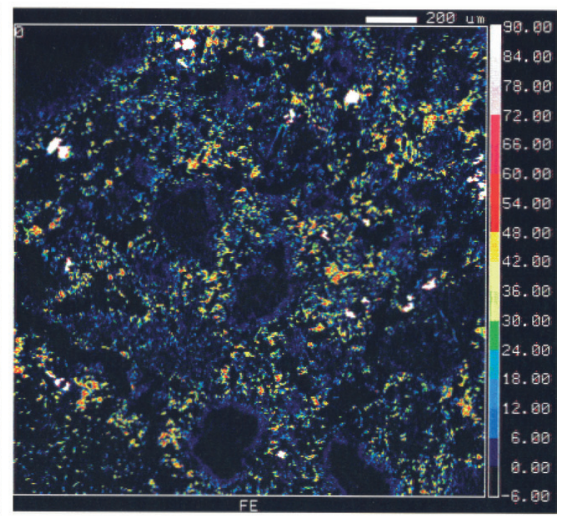

$200 \mu \mathrm{m}$

Fig. 17. EPMA of the heat-treated silica brick retort (b) iron ore powder, $1100^{\circ} \mathrm{C}$; (d) iron ore powder, $1200^{\circ} \mathrm{C}$. 


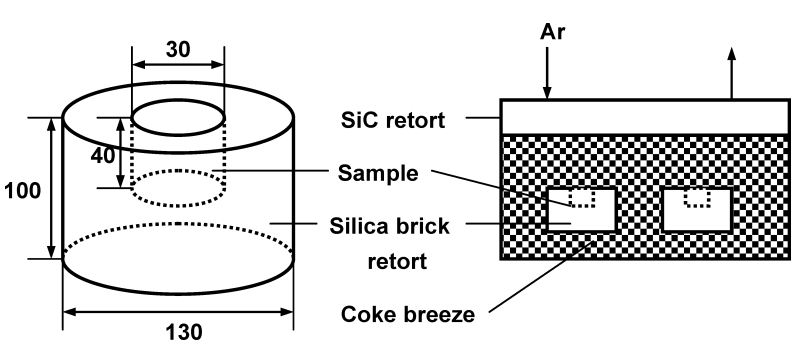

Fig. 13. The silica brick retort and the heat-treatment experimental apparatus.

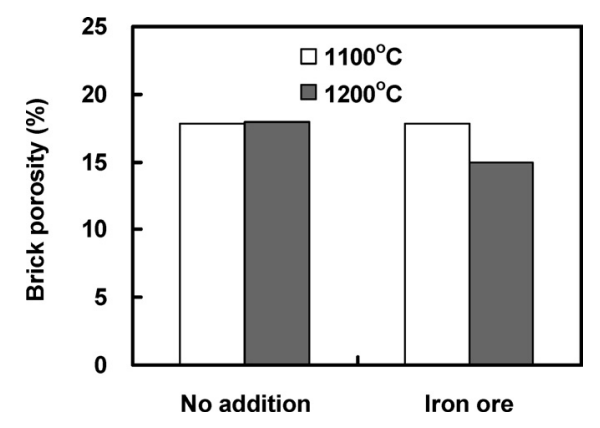

Fig. 15. The porosity of heat-treated silica brick.

coal/iron ore powder mixture. These values are close to the mass ratio of total $\mathrm{Fe}$ to iron oxide $(71 \%)$ in the iron ore powder. This shows that most iron oxides are reduced to metallic iron by $\mathrm{CO}$ and $\mathrm{H}_{2}$ which are generated during coal carbonization. Determining the gas that functions as a reducing agent for iron oxides, by analyzing the decomposition gas, is a subject for future study.

\section{Effect of Iron Ore Powder on the Coke Oven Wall Silica Brick}

\subsection{Experimental}

As shown in Fig. 13, iron ore powder was charged in a silica brick retort (outer dimension: $\phi 130 \times \mathrm{h} 100 \mathrm{~mm}$, sample cell: $\phi 30 \times \mathrm{h} 40 \mathrm{~mm})$. In order to simulate the reaction of iron ore powder and silica brick in actual coke oven chamber conditions, this retort was placed in a $\mathrm{SiC}$ retort filled with coke breeze and heat-treated at $1100^{\circ} \mathrm{C}$ and $1200^{\circ} \mathrm{C}$ in an $\mathrm{Ar}$ atmosphere for $48 \mathrm{~h}$ (for $5 \mathrm{~d}$ including the period of raising and lowering temperature).

The porosity and the microstructure of the heat-treated silica brick located near iron ore powder were analyzed. Moreover, the heat-treated silica brick retort was analyzed using SEM and EPMA.

\subsection{Results and Discussion}

The cross-sectional views of the heat-treated silica brick retort are shown in Figs. 14(a)-14(d). In the case of $1100^{\circ} \mathrm{C}$, iron ore powder gives no changes; however, in the case of $1200^{\circ} \mathrm{C}$, iron ore powder greatly eroded and damaged the retort and a circular part with a different color is observed around the eroded part. The reasons why Figs. 14(b) and 14(d) look whiter than Figs. 14(a) and 14(c) are due to a stain left during cutting the retort and/or a difference in the color of the base silica brick.

Figure 15 shows that in the case of $1100^{\circ} \mathrm{C}$, iron ore powder has no effects on the porosity of the silica brick;
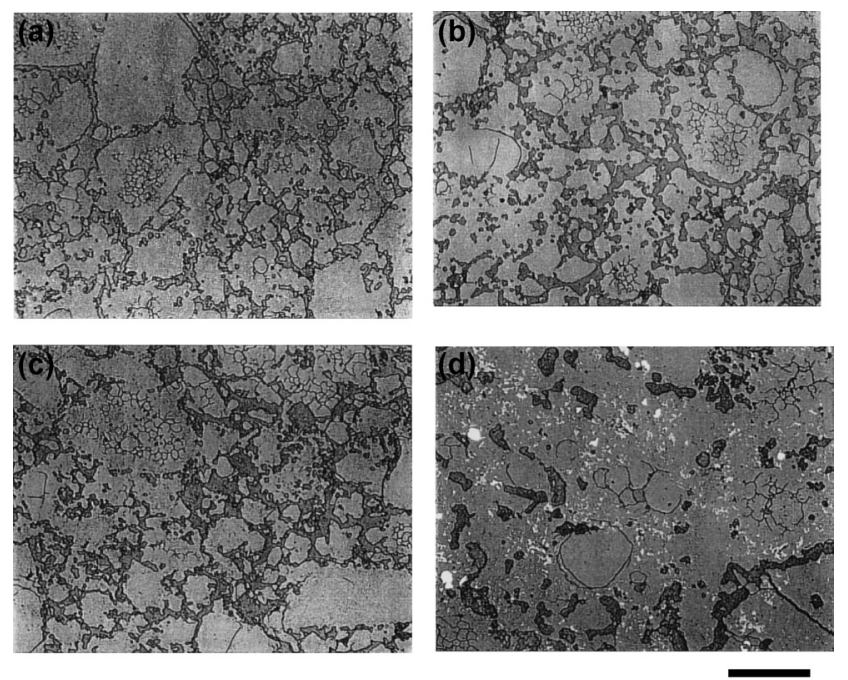

$500 \mu \mathrm{m}$

Fig. 16. The microstructure of the heat-treated silica brick retort (a) no addition, $1100^{\circ} \mathrm{C}$; (b) iron ore powder, $1100^{\circ} \mathrm{C}$; (c) no addition, $1200^{\circ} \mathrm{C}$; (d) iron ore powder, $1200^{\circ} \mathrm{C}$.

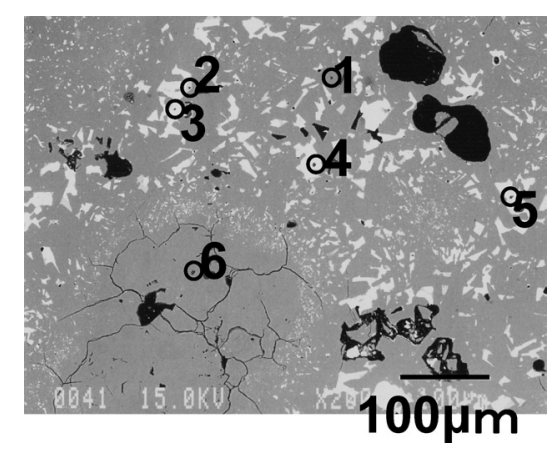

Fig. 18. The SEM image of the heat-treated silica brick retort (iron ore powder, $1200^{\circ} \mathrm{C}$ ) and the positions of the EPMA spot analysis.

however, in the case of $1200^{\circ} \mathrm{C}$, it decreases the brick porosity. $\mathrm{FeO}$ and $\mathrm{SiO}_{2}$ can produce fayalite $\left(2 \mathrm{FeO} \cdot \mathrm{SiO}_{2}\right)$ over $1175^{\circ} \mathrm{C}$. In the case of $1200^{\circ} \mathrm{C}$, the main component of the silica brick, $\mathrm{SiO}_{2}$, and $\mathrm{FeO}$ in iron ore powder reacted to produce a low melting compound, which eroded and damaged the silica brick. This melting compound fills the pores in the brick and hence decreases the porosity.

Figure 16 shows the microstructure of the heat-treated silica brick retort. The microstructure of the silica brick heat-treated with iron ore powder at $1200^{\circ} \mathrm{C}$ (d) is different from the others in that the area of the pores is smaller and that some bright spots are observed.

Figure 17 shows the EPMA mass analysis of the heattreated silica brick retort. It is clear that a large quantity of iron penetrates the silica brick heat-treated with iron ore powder at $1200^{\circ} \mathrm{C}(\mathrm{d})$. Figure 18 shows the SEM image of the silica brick heat-treated with iron ore powder at $1200^{\circ} \mathrm{C}$ and chemical compositions at 6 spots in the SEM image were analyzed by EPMA. As shown in Table 5, the compound of the bright spots (No. 3, 4 and 5) is identified as fayalite $\left(2 \mathrm{FeO} \cdot \mathrm{SiO}_{2}\right)$. 
Table 5. The EPMA spot analysis results of the heat-treated silica brick retort (iron ore powder, $1200^{\circ} \mathrm{C}$ ).

\begin{tabular}{|c|c|c|c|c|c|c|c|c|c|c|}
\hline \multirow{2}{*}{ No. } & \multicolumn{5}{|c|}{ Composition (mass \%) } & \multicolumn{4}{c|}{ Atom number ratio (-) } & \multirow{2}{*}{ Compound } \\
\cline { 2 - 10 } & Al & Si & Ca & Fe & O & O/AI & O/Si & O/Ca & O/Fe & \\
\hline 1 & & 46.4 & & 0.2 & 53.3 & - & 2.0 & - & 929.4 & SiO $_{2}$ \\
\hline 2 & 5.4 & 26.1 & 9.6 & 12.1 & 46.9 & 14.7 & 3.2 & 12.2 & 13.5 & \\
\hline 3 & & 15.5 & 0.4 & 53.9 & 29.6 & - & 3.4 & 185.0 & 1.9 & $2 \mathrm{FeO} \cdot \mathrm{SiO}_{2}$ \\
\hline 4 & 0.1 & 16.3 & 0.4 & 53.8 & 29.1 & 491.1 & 3.1 & 181.9 & 1.9 & $2 \mathrm{FeO} \cdot \mathrm{SiO}_{2}$ \\
\hline 5 & 0.2 & 17.1 & 0.4 & 51.6 & 30.4 & 256.5 & 3.1 & 190.0 & 2.1 & $2 \mathrm{FeO} \cdot \mathrm{SiO}_{2}$ \\
\hline 6 & & 49.5 & & & 50.5 & - & 1.8 & - & - & SiO $_{2}$ \\
\hline
\end{tabular}

Table 6. Properties of the iron coke produced in a commercial coke oven chamber.

\begin{tabular}{|c|c|c|c|c|c|c|c|c|}
\hline $\begin{array}{c}\mathrm{DI}^{150}{ }_{15} \\
(-)\end{array}$ & $\begin{array}{c}\mathrm{D}^{150}{ }_{6} \\
(-)\end{array}$ & $\begin{array}{c}\text { Mean size } \\
(\mathrm{mm})\end{array}$ & $\begin{array}{c}\text { Apparent density } \\
\left(\mathrm{g} / \mathrm{cm}^{3}\right)\end{array}$ & $\begin{array}{c}\text { True density } \\
\left(\mathrm{g} / \mathrm{cm}^{3}\right)\end{array}$ & $\begin{array}{c}\text { Porosity } \\
(\%)\end{array}$ & $\begin{array}{c}\text { CRI } \\
(-)\end{array}$ & $\begin{array}{c}\text { CSR } \\
(-)\end{array}$ & $\begin{array}{c}\text { JIS Rel } \\
(-)\end{array}$ \\
\hline 80.9 & 82.7 & 47.3 & 1.07 & 2.06 & 47.9 & 48.8 & 16.3 & 40.5 \\
\hline
\end{tabular}

Table 7. Ultimate analysis and ash components of the iron coke produced in a commercial coke oven chamber.

\begin{tabular}{|c|c|c|r|r|r|r|r|r|r|r|r|r|r|}
\hline \multicolumn{1}{|c|}{$\begin{array}{c}\text { Ultimate analysis } \\
\text { (mass\%, db) }\end{array}$} & \multicolumn{10}{|c|}{ Major component in coke ash (mass\%) } \\
\hline $\mathrm{VM}$ & $\mathrm{Ash}$ & $\mathrm{TS}$ & $\mathrm{P}_{2} \mathrm{O}_{5}$ & $\mathrm{~K}_{2} \mathrm{O}$ & $\mathrm{Na}_{2} \mathrm{O}$ & $\mathrm{SiO}_{2}$ & $\mathrm{Al}_{2} \mathrm{O}_{3}$ & $\mathrm{Fe}_{2} \mathrm{O}_{3}$ & $\mathrm{CaO}$ & $\mathrm{MgO}$ & $\mathrm{MnO}$ & $\mathrm{TiO}_{2}$ & $\mathrm{SO}_{3}$ \\
\hline $\mathbf{0 . 3 1}$ & $\mathbf{1 8 . 9 2}$ & $\mathbf{0 . 4 9}$ & $\mathbf{0 . 5 2}$ & $\mathbf{0 . 4 7}$ & $\mathbf{0 . 2 5}$ & $\mathbf{3 0 . 2 2}$ & $\mathbf{1 6 . 2 7}$ & $\mathbf{4 8 . 3 4}$ & $\mathbf{0 . 9 3}$ & $\mathbf{0 . 6 4}$ & $\mathbf{0 . 0 6}$ & $\mathbf{1 . 0 3}$ & $\mathbf{0 . 3 0}$ \\
\hline
\end{tabular}

\section{Production Test of Iron Coke in a Commercial Scale Coke Oven}

\subsection{Experimental}

Based on the above fundamental study, in order to produce highly reactive iron coke to satisfy the coke strength required for an actual blast furnace operation, iron coke was produced in a commercial scale coke oven chamber. Based on the results in Figs. 5 and 8, the blend coal B3 (close to blend coal B4 in VM and total dilatation) was prepared and the blending ratio of iron ore powder was decided as $6.5 \%$. The blended coal and iron ore powder were discharged from different hoppers and iron ore was added on coal on a belt conveyer. Since coal and iron ore powder are transported to a coke oven chamber through 8 conveyors and mixed when transferred from one conveyor to another, they were not mixed using a mixer. The coal moisture was $8.0 \%$. In order to avoid the reaction of $\mathrm{FeO}$ and $\mathrm{SiO}_{2}$, the target oven temperature at the flue bottom was set at $1250^{\circ} \mathrm{C}$ or less, considering the difference in temperature (minimum $150^{\circ} \mathrm{C}$ ) between the flue and the wall surface in a coke oven chamber (the average measured flue bottom temperature was $1230^{\circ} \mathrm{C}$ ). The total carbonization period was $24 \mathrm{~h}$ and discharged coke was quenched by water.

\subsection{Results and Discussion}

As shown in Table 6, JIS $\mathrm{R}_{\mathrm{e}} \mathrm{I}$ of the wet quenched coke is as high as 40.5 and $\mathrm{DI}^{150}{ }_{15}$ is 80.9. Since CDQ process increases $\mathrm{DI}^{150}{ }_{15}$ by $\left.1.5,{ }^{18}\right)$ the estimated $\mathrm{DI}^{150}{ }_{15}$ of dry quenched coke will be 82.4 , which satisfies the coke strength required for an actual blast furnace operation. Discharging the iron coke out of the oven (i.e. coke cake pushing) was as normal as usual. We did not observe any negative effects of the coal/iron ore powder mixture charge in a coke oven chamber on coke oven walls.

As shown in Table 7, the ash content and the $\mathrm{Fe}_{2} \mathrm{O}_{3}$ content in ash of the iron coke is higher than those of normal coke due to the addition of iron ore powder. Furthermore, as shown in Table 8, iron oxides in iron ore powder are reduced to metallic iron during the carbonization process and
Table 8. Chemical compositions of iron in the iron coke produced in a commercial coke oven chamber.

\begin{tabular}{|c|c|c|c|}
\hline \multicolumn{4}{|c|}{ Chemical composition (mass\%) } \\
\hline T.Fe & Metal & $\mathrm{Fe}^{2+}$ & $\mathrm{Fe}^{3+}$ \\
\hline 7.92 & 5.24 & 1.67 & 1.01 \\
\hline
\end{tabular}

the reduction degree is about $70 \%$. Considering that most iron oxides of the dry quenched iron coke produced in a laboratory scale experiment are reduced to metallic iron, some metallic iron may have been re-oxidized during the wet quenching and handling process in a commercial scale production test. This infers that the usage of iron coke in a blast furnace could improve the efficiency of blast furnace reactions not only because iron coke is highly reactive, but also because part of the iron oxides in iron coke are already reduced to metallic iron by reducing gases such as $\mathrm{CO}$ and $\mathrm{H}_{2}$ which are generated during coal carbonization.

\section{Conclusions}

In order to clarify the production method of iron coke in a slot-type coke oven chamber to satisfy the coke quality such as strength and reactivity required for an actual blast furnace operation, we investigated the effect of catalytic Fe powder (fine iron ore powder, iron agent) added to coal before carbonization on coke quality and the effect of Fe powder on the silica brick in actual coke oven chamber conditions. Then, based on the fundamental study, highly reactive iron coke was produced in a commercial scale coke oven chamber on trial.

(1) The addition of catalytic Fe powder decreases the coal caking property and hence the resultant coke drum index $\left(\mathrm{DI}^{150}{ }_{15}\right)$. On the other hand it increased coke reactivity (JIS coke reactivity index and CRI) to a great extent. The caking property of blended coals needs to be adjusted higher to produce iron coke with proper strength and high reactivity.

(2) The iron ore reacts with silica brick at $1200^{\circ} \mathrm{C}$ in a condition similar to that in a coke oven chamber to produce fayalite $\left(2 \mathrm{FeO} \cdot \mathrm{SiO}_{2}\right)$ and the brick is damaged. On the 
other hand, the iron ore does not react with silica brick at $1100^{\circ} \mathrm{C}$ in the above condition.

(3) The iron coke with proper strength $\left(\mathrm{DI}^{150}{ }_{15}^{80.9 \text {, }}\right.$ equivalent to 82.4 after CDQ) and high reactivity (JIS $R_{e} I$ 40) was successfully produced in a coke oven chamber on a commercial scale by adjusting the coal blend composition and the coke oven temperature. Furthermore, about $70 \%$ of iron in the iron ore powder added to coal was reduced to metallic iron during carbonization.

We will further study the strength of highly reactive iron coke after reaction and also the effect of iron coke on the thermal reserve zone temperature with an adiabatic blast furnace simulator.

\section{REFERENCES}

1) M. Naito, A. Okamoto, K. Yamaguchi, T. Yamaguchi and Y. Inoue: Tetsu-to-Hagané, 87 (2001), 357.

2) S. Nomura, H. Kitaguchi, K. Yamaguchi and M. Naito: ISIJ Int., 47 (2007), 245

3) S. Nomura, H. Ayukawa, H. Kitaguchi, T. Tahara, S. Matsuzaki, M. Naito, S. Koizumi, Y. Ogata, T. Nakayama and T. Abe: ISIJ Int., 45 (2005), 316.
4) G. Granger, M. J. Lach and J. Mitchell: AIME Blast Furnace, Coke Oven, and Raw Materials Conf., American Institute of Mining, Metallurgical and Petroleum Engineers, Inc., New York, NY, (1959), 152.

5) H. Barking and C. Eymann: Brennst.-Chemie, 37 (1956), 129.

6) Japanese Industrial Standard JIS M8801 (1993): Coal-Testing Methods.

7) S. Nomura, T. Arima and K. Kato: Fuel, 83 (2004), 1771.

8) M. Kiyotomo: Coke Circular, 30 (1981), 13.

9) Japanese Industrial Standard JIS K 2151 (1993): Coke-Testing Methods.

10) N. Nakamura, Y. Togino and M. Tateoka: Ironmaking Steelmaking, 5 (1978), 1.

11) T. Arima: Tetsu-to-Hagané, 87 (2001), 274.

12) A. Tomita, T. Takarada and Y. Tamai: Fuel, 62 (1983), 62.

13) Y. Ohtsuka, Y. Kuroda, Y. Tamai and A. Tomita: Fuel, 65 (1986), 1476.

14) Y. Kashiwaya, S. Nakaya and K. Ishii: Tetsu-to-Hagané, 77 (1991), 759.

15) K. Yamaguchi and T. Uno: J. Jpn. Inst. Energy, 78 (1999), 760.

16) S. Watakabe and K. Takeda: Tetsu-to-Hagané, 87 (2001), 467.

17) S. Nomura, M. Naito and K. Yamaguchi: Tetsu-to-Hagané, 93 (2007), 9.

18) H. Uematsu, Y. Ishida and K. Kushioka: Proc. of 48th Ironmaking Conf., ISS, Warrendale, PA, (1989), 109. 